Meta

Journal des traducteurs

Translators' Journal

\title{
Political Routines in Press Translation
}

\section{Petros Kontos et Maria Sidiropoulou}

Volume 57, numéro 4, décembre 2012

Journalisme et traduction

Journalism and Translation

URI : https://id.erudit.org/iderudit/1021230ar

DOI : https://doi.org/10.7202/1021230ar

Aller au sommaire du numéro

\section{Éditeur(s)}

Les Presses de l’Université de Montréal

\section{ISSN}

0026-0452 (imprimé)

1492-1421 (numérique)

Découvrir la revue

\section{Citer cet article}

Kontos, P. \& Sidiropoulou, M. (2012). Political Routines in Press Translation. Meta, 57(4), 1013-1028. https://doi.org/10.7202/1021230ar

\section{Résumé de l'article}

Le présent article vise à démontrer que les journalistes-traducteurs, lorsqu'ils décident de conserver ou de supprimer des éléments du texte source dans l'espace restreint qui leur est accordé par les journaux en langue cible, agissent selon des connaissances contextuelles. De telles décisions montrent qu'ils tiennent compte des programmes politiques, en plus des contraintes générales, des priorités narratives, des préférences idiomatiques, etc. La prise en compte de ces éléments, qui relèvent de la pragmatique, permet de déceler les intentions de l'auteur. Nous nous pencherons sur deux paires (texte source/texte cible) d'articles traitant du premier ministre anglais Tony Blair. Ces deux articles, publiés en 2007, proviennent du Guardian et du New York

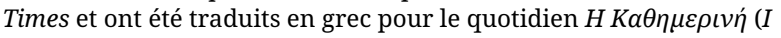
Kathimerini). Nous présenterons certaines interventions linguistiques et culturelles qui assurent l'acceptabilité du texte cible et montrerons que le choix des informations retenues est, entre autres, régi par la connaissance théorique du contexte politique. En l'occurrence, nous postulons la perception de la notion de représentation politique qui varie selon les cultures et la prise en compte des caractéristiques du présidentialisme selon Heywood, souvent affiché par les parlementaires.
Ce document est protégé par la loi sur le droit d'auteur. L’utilisation des services d’Érudit (y compris la reproduction) est assujettie à sa politique d'utilisation que vous pouvez consulter en ligne.

https://apropos.erudit.org/fr/usagers/politique-dutilisation/ 


\title{
Political Routines in Press Translation
}

\author{
PETROS KONTOS \\ National and Kapodistrian University of Athens, Athens, Greece \\ petros_kontos_ekpa@yahoo.gr
}

\section{MARIA SIDIROPOULOU}

National and Kapodistrian University of Athens, Athens, Greece msidirop@enl.uoa.gr

\begin{abstract}
RÉSUMÉ
Le présent article vise à démontrer que les journalistes-traducteurs, lorsqu'ils décident de conserver ou de supprimer des éléments du texte source dans l'espace restreint qui leur est accordé par les journaux en langue cible, agissent selon des connaissances contextuelles. De telles décisions montrent qu'ils tiennent compte des programmes politiques, en plus des contraintes générales, des priorités narratives, des préférences idiomatiques, etc. La prise en compte de ces éléments, qui relèvent de la pragmatique, permet de déceler les intentions de l'auteur. Nous nous pencherons sur deux paires (texte source/texte cible) d'articles traitant du premier ministre anglais Tony Blair. Ces deux articles, publiés en 2007, proviennent du Guardian et du New York Times et ont été

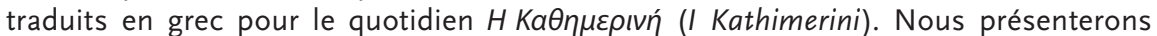
certaines interventions linguistiques et culturelles qui assurent l'acceptabilité du texte cible et montrerons que le choix des informations retenues est, entre autres, régi par la connaissance théorique du contexte politique. En l'occurrence, nous postulons la perception de la notion de représentation politique qui varie selon les cultures et la prise en compte des caractéristiques du présidentialisme selon Heywood, souvent affiché par les parlementaires.
\end{abstract}

\section{ABSTRACT}

The paper aims at showing that the journalist-translators' decision-making with respect to what is to be included or left out of a target text, in the limited space provided by target newspapers, is governed by background knowledge considerations which reveal awareness of current political routines - in addition to generic constraints, narrative priorities, language-specific preference, etc. This is a pragmatic level of meaning which contributes to realizing the intention of the text producer. The paper examines two source text/target text pairs of articles on Tony Blair's premiership, from The Guardian and The

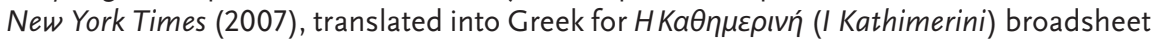
newspaper. It presents an overview of linguistic/cultural shifts which ensure acceptability in the target text, and shows that information selection/reduction adheres - inter alia - to political theoretical background knowledge: in this case, it assumes perception of the notion of political representation, which may vary across cultures, and awareness of the features of presidentialism according to Heywood, which parliamentary executives' conduct often exhibits. Findings underline the multi-faceted task of journalist-translators and call for a multidisciplinary approach to news translation, which would encompass political theory perspectives, in addition to linguistic and journalistic perspectives to variation.

\section{MOTS-CLÉS/KEYWORDS}

presse, programme politique, interculturalité, acceptabilité, politique press, political routines, interculturality, acceptability, politics 
The process of media production, then, is one which can be studied, understood and manipulated by those who wish to gain access [...].

(McNair 1995/2011: 64)

\section{Media, communication and translation}

If ideology is "any constellation of fundamental or commonsensical, and often normative, beliefs and ideas related to some aspect(s) of (social) 'reality"' (Verschueren 1999: 238), a translation researcher's concern would be to examine the dynamics of this implicit, commonsensical, unquestioned meaning emerging from source texts (ST) and target texts (TT). This is a pragmatically oriented type of research which seeks to highlight the potential of texts (in the case of translation, the potential of source and target texts) to make meaning and construct identities, often with farreaching ramifications. This is particularly true in the language of the media - and media translation, where languages in contact provide manifestations of some longestablished conflicts for world dominance (Valdeón 2011). Translation researchers and discourse analysts are highly motivated to explore such discourse phenomena, in their attempt to unveil ethnocentric perspectives and domination techniques, or search for strategies of legitimization, textual traditions, etc.

Press translation research has focused on linguistic/socio-cultural, journalistic and ideological aspects of message construction (Baker 2006; Bielsa and Bassnett 2009; van Leeuwen 2011), which journalist-translators adhere to in order to produce a target version that would conform to generic constraints, intended narrative priorities, etc. This is what Munday (2001/2008: 190) calls "a dynamic shifting interaction between relevant elements of the linguistic toolkit and cultural analysis." These aspects of meaning reveal the intention (and strategies) of the media to exercise power and construct identities, or reflect aspects of identity of a source/target readership. Institutional practices and translational conventions interact to adjust news products to consumer taste or sustain an intended power balance; this seems to be a process which often yields awkward results. Valdeón, for instance, in examining texts produced by the Spanish Service of the BBC, claims that "BBC Mundo texts offer numerous instances where the combination of editorial routines and translational processes produce ambiguity, opacity, misunderstandings or misinformation" (Valdeón 2005: 217).

Van Leeuwen (2011) examines types of press translation shifts in the English version of a Vietnamese paper. Although the translation direction in van Leeuwen's study (from localized to global) is different from that of the present study, which instead examines localization of the global, the study provides a useful background for the shift types traced in the present data. Van Leeuwen identifies levels of translator-journalist's intervention: in rewriting local texts for the global market, he claims, sub-editors of the international version of the Vietnam News daily newspaper make translation/adaptation decisions, on three levels. These are

- translation decisions affecting the English used;

- translation/adaptation decisions affecting the journalistic style;

- translation/adaptation decisions affecting cultural and ideological references in the source texts. 
In the first category of shifts, van Leeuwen groups shifts under tense and attribution, nominalization and conciseness, vocabulary and idiom. Under "stylistic adaptation," reference is made to leads (the short summaries offering an introduction to the news story), accuracy and attribution. Under "cultural and ideological adaptation," van Leeuwen refers to repositioning the reader through processes such as "unpacking of Vietnamese concepts and terminology," "preconceptions about Vietnam or the 'Orient'” (van Leeuwen 2011: 230), etc.

Translation research (and discourse studies) have often focused on this third level of ideological meaning adaptation, in an attempt to theoretically account for aspects of what may be described as background knowledge and its contribution to meaning-making: prioritization of info transfer, changes in angle (Bielsa and Bassnett 2009), narratives (Baker 2006), etc. In the Critical Discourse Analysis (CDA) framework, the last two categories of shifts in van Leeuwen's analysis relate to "the institutional and wider social and cultural context of media practices" (Fairclough 1995: 33), which need to be analyzed for a coherent view of discourse practices to be articulated.

Our intention is to focus on the third level of van Leeuwen's analysis, namely, on the level of cultural/ideological meaning-making, because the background knowledge it assumes is rather underspecified in current multifaceted social reality. Although the first level (of linguistic practices) and the second level (journalistic routines) seem to display variation along a finite, identifiable set of rules (grammar/ discursive and journalistic routines), the third level of van Leeuwen's analysis refers to background knowledge, which is too broad to be accounted for by a single theoretical model, and seems to be constantly displaying additional aspects of meaningmaking, which are manipulated in authentic translation situations.

All three levels are worth examining as there seems to be room for contributing insights into how these levels can be perspectivized to account for phenomena of cross-cultural variation in linguistic, journalistic and ideological practices.

The next section draws on two pairs of ST(English)/TT(Greek) press articles to present an overview of shifts which manifest variation in the linguistic/cultural, institutional and ideological practices, in the English-Greek context. The study will then go on to show politically relevant theoretical information which seems to affect content selection practices in press translation. Awareness of the contribution of politically relevant background information bears consequences for press translation training and enlightens exploration of the implicit unquestioned meaning emerging from texts (Verschueren 1999) in political communication arenas, which press translation is a part of.

\section{Data analysis}

The paper takes a qualitative approach to the data and engages in revealing processes of political communication through press translation. It examines two articles on Tony Blair's premiership, from The Guardian and The New York Times, translated for $H$ K $\alpha \theta \eta \mu \varepsilon \rho \iota \eta \dot{~(I ~ K a t h i m e r i n i) ~ b r o a d s h e e t ~ n e w s p a p e r ~(2007) . ~ T h e ~ a r t i c l e s ~ d i s p l a y ~ a ~}$ different ideological intention, pro and against the prime minister, (respectively), evidently in line with the pluralist view of media impact (highlighting diversity and multiplicity of opinion). These articles are: Like it or Loathe it, After 10 Years Blair 
Knows Exactly What He Stands For (Ash 26 April 2007) ${ }^{1}$ and its translation into Greek (Ash 27 April 2007)2 , and Tony Blair, Three-Time Loser (Gill 24 June 2007) ${ }^{3}$ and its translation into Greek (Gill 1 July 2007) ${ }^{4}$.

As the headlines suggest, Ash (26 April 2007), from The Guardian, takes a favorable attitude towards Mr. Blair, while Gill (24 June 2007), from The New York Times, fosters a predominantly negative gloss. The target versions display a comparable ideological stance, with that of the source articles, but they register a range of shifts which may be categorized and analyzed, with a view to charting translator behavior and singling out those shifts which the present study intends to highlight, namely shifts which assume awareness of political theoretical background knowledge, capable of constructing intended identities.

In agreement with the Martin and Nakayama (2003) view on approaches to intercultural communication, the study further categorizes the shifts traced in the data, with reference to their assumed type of motivation and predictability. It identifies

- predictable behavior (of the journalist-translators), which reveals instances of communication influenced by culture (a social science approach);

- creative and voluntary behavior, which reveals that culture is created and maintained through communication (the interpretive approach);

- changeable behavior, which presents culture as a site of power struggles (the critical approach).

(Martin and Nakayama 2003: 48)

The Martin and Nakayama tripartite distinction is not a stand-alone one. Political reality has been described as comprising three categories: objective political reality "comprising political events as they actually occur," subjective reality - "reality of the political events as they are perceived by actors and citizens," and constructed reality, "meaning events as covered by the media" (McNair 1995/2011: 11). The Martin and Nakayama (2003) "predictable behavior" seems to correspond to the "objective" perspective from which political reality is approached in McNair's view, as predictable behavior (preference for one or another feature in communication) assuming a social science perspective can be objectively verified through data. The Martin and Nakayama (2003) "creative and voluntary behavior" assumes an interpretive motivation and may correspond to McNair's subjective reality of political events as perceived by participants. On a par, the Martin and Nakayama (2003) "changeable behavior," which assumes a power struggle perspective, seems to correspond to McNair's constructed reality, in that the events covered by the media reflect the media-public power imbalance and the power of the media to shape (political or other) messages in favor of intended ideological perspectives.

Instances of variation in the objective, subjective, constructed reality are presented below, though categorization can never be absolute, because the dynamics of language can always give phenomena (and shifts) an unprecedented potential.

\subsection{Predictable behavior}

Predictable behavior would include shifts motivated by linguistic/cultural preference, namely shifts systematically manifested on the Greek side, in English-Greek news transfer (Sidiropoulou 2004; 2008). They may carry ideological significance (most 
probably related to the linguistic identities of the languages in contact). Such shifts may include a tendency of the Greek version of texts for

- raising tenor (in the news reporting genre),

- strengthening cohesion (e.g., highlighting adversative and causal relations),

- favoring deictic specificity,

- privileging positive politeness clues like assertiveness and evaluation,

- highlighting uncertainty avoidance and long-term orientation clues, etc.

The following examples show traces of shifts in the Blair articles which have systematically been identified on the Greek side in English-Greek translation contexts, no matter the direction of translation. In Gill (1 July 2007), translated by the newspaper I Kathimerini (Example [1]), the underlined expression manifests a higher level of formality in TT, which evidently enhances persuasion, and has been systematically traced in news reporting and EU translation (Sidiropoulou 2004; 2008).

(1) [...] Blair has managed to get himself [...] hated at home.

(Gill 24 June 2007)

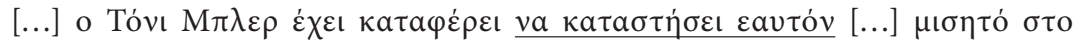
$\varepsilon \sigma \omega \tau \varepsilon \rho$ เко́.

[(...) Tony Blair has managed to make (formal) himself (...) hated at home.]

(Gill 1 July 2007; translation by I Kathimerini; back-translation and emphasis by the authors)

Target texts in the following Examples (2), (3) and (4) strengthen adverbial cohesion: TT enforces the contrastive network by adding an adversative connective, $\alpha \lambda \lambda \dot{\alpha}$ [but], in TT expression a regal trait but in a democracy framework, to render ST item regal touch for the republic. The shift is highly predictable, a rather strong preference in English-Greek transfer (Sidiropoulou 2004; 2008) and may be identified through a social science perspective to translation data.

(2) And every president leaves office with his title. He will always be Mr. President, a peculiarly regal touch for the republic. But when he wakes up on Thursday, the prime minister will be plain Mr. Blair, MP.

(Gill 24 June 2007)

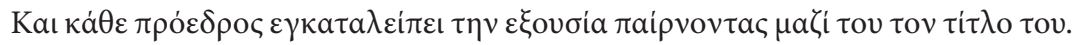

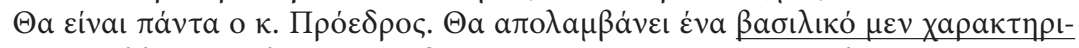

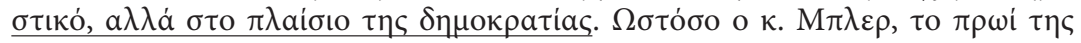

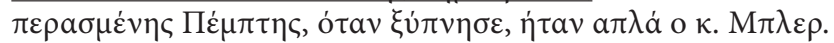

[And every president leaves office taking his title with him. He will always be Mr. President. He will enjoy a peculiarly regal trait but in a democracy framework. However, when Mr. Blair woke up last Thursday morning, he was plain Mr. Blair.]

(Gill 1 July 2007; translation by I Kathimerini; back-translation and emphasis by the authors)

The same goes for causal relations, which are highlighted in every way in the Greek target version: in Example (3), ST item starting from (Ash 26 April 2007) is

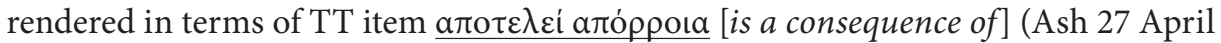
2007). Likewise, in Example (4), ST item putting his finger on (Gill 24 June 2007) is 
rendered in terms of TT $\dot{\varepsilon} \varphi \theta a \sigma \varepsilon[. ..] \sigma \tau \eta v \varepsilon \xi \dot{\eta} \gamma \eta \sigma \eta$ [reached (...) an explanation] (Gill 1 July 2007) where the cause-and-effect relationship between propositions is more salient on the Greek side. The shifts manifest a concern of the Greek translator to be enforcing logical relations in the text, as a device enhancing persuasion (Sidiropoulou 2004; 2008; Kontos and Sidiropoulou 2012) and improving texture.

(3) Blairism is, he elaborates, about a progressive view of the world, starting from the reality of interdependence in the age of globalization, [...]

(Ash 26 April 2007)

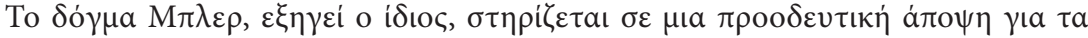

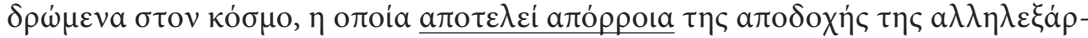

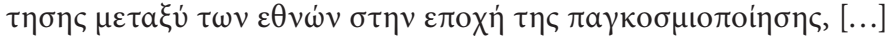

[The Blair doctrine, he explains, is based on a progressive view about the world which is a consequence of accepting interconnectedness among nations, in the age of globalization (...)]

(Ash 27 April 2007; translation by I Kathimerini; back-translation and emphasis by the authors)

(4) It was Tom Paine, [...] who came closest to putting his finger on why we so resolutely hate our politicians on principle.

(Gill 24 June 2007)

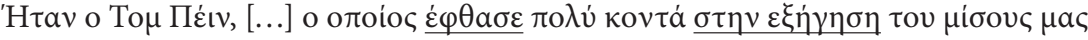

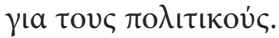

[It was Tom Paine, (...) who came closest to the explanation of our hatred about politicians.]

(Gill 1 July 2007; translation by I Kathimerini; back-translation and emphasis by the authors)

Deictic specificity is often favored in Greek (Greeks, for instance, tend to overuse the definite article in their production in English due to mother tongue interference). In the present data set, preference for specificity is manifested through addition of the adverb $\tau \dot{\omega} \rho \alpha[n o w]$ in the following TT from Gill (1 July 2007), which enforces the dramatic present effect preferred by the translator:

(5) $[\mathrm{H}] \mathrm{e}$ 'd done his best. But it counts for naught. He'll leave office...

(Gill 24 June 2007)

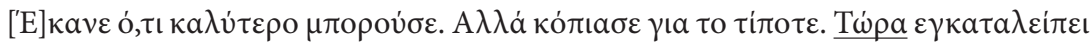
$\tau \eta v \varepsilon \xi o v \sigma i \alpha . .$.

$[(\mathrm{H}) \mathrm{e}$ 'd done his best. But he got tired for nothing. Now, he is leaving office...]

(Gill 1 July 2007; translation by I Kathimerini; back-translation and emphasis by the authors)

Greek is a positive politeness language (Sifianou 1992) and thus favors - among other things - evaluation devices. TT in Example (6) shows two instances of evalu-

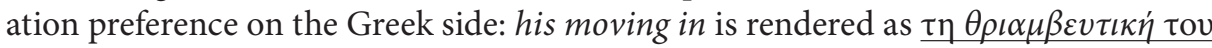

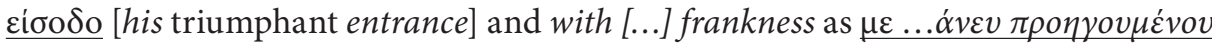

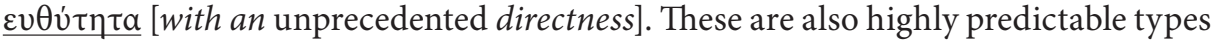
of linguistic behavior attributed to the positive politeness character of the language. 
(6) As he approaches the 10th anniversary of his moving in No 10, next Wednesday, [...] he talks about his decade of shaping British foreign policy with an ease and frankness...

(Ash 26 April 2007)

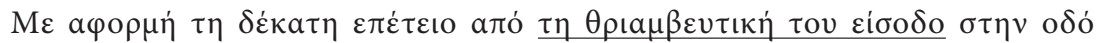

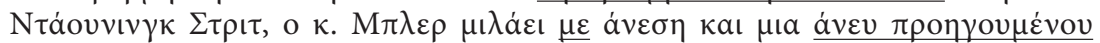

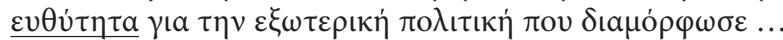

[On the occasion of the $10^{\text {th }}$ anniversary of his triumphant entrance to the Downing Street (building), Mr. Blair talks with ease and with an unprecedented directness about the foreign policy he shaped.]

(Ash 27 April 2007; translation by I Kathimerini; back-translation and emphasis by the authors)

The next two examples display evidence of traits attributed to Greek social behavior in Hofstede and Hofstede's model of intercultural communication styles (Hofstede and Hofstede 2005). Two of the five verbal communication style dimensions referred to in Hofstede and Hofstede's model (2005) are realized in the present data, with the target version verifying its uncertainty avoidance tendency attributed to Greek social reality and its long-term orientation: the uncertainty avoidance tendency on the Greek side is manifested in strengthening cohesion (Examples [3] and [4]), in the preference

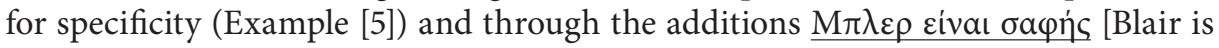

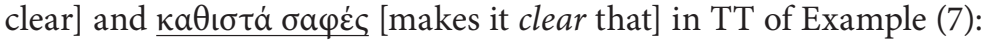

(7) I turn to those alliances with Europe and the US. [...] British attitudes remain stolidly Eurosceptic." A great deal of that is due to the Eurosceptic media. [...] the British people are sensible enough to know that, even if they have a certain prejudice about Europe, they don't expect their government to share it or act upon it.

(Ash 26 April 2007)

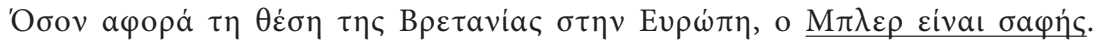

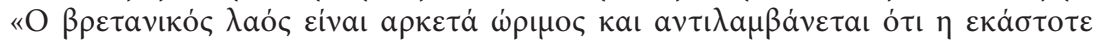

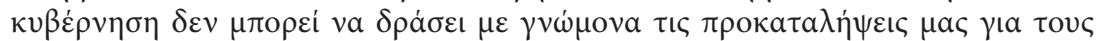

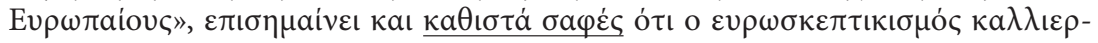

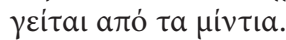

[As far as the place of Britain in Europe is concerned, Blair is clear. "The British people are sensible enough to understand that, whatever the government, it cannot act upon our prejudice about Europeans" he claims and makes it clear that Euroscepticism is cultivated by the media.]

(Ash 27 April 2007; translation by I Kathimerini; back-translation by the authors)

It is as if "being clear" in communication is a value (no matter how clarity may be defined). A long-term orientation tendency is manifested, in the present data,

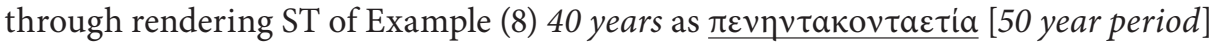
in TT: the shift favors a future, long-term orientation on the Greek side, as manifested elsewhere in English-Greek news translation practice (Sidiropoulou 2004).

(8) Most prime ministers over the last 40 years would have agreed.

(Ash 26 April 2007) 


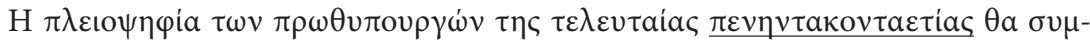
$\varphi \omega v o u ́ \sigma a v$.

[The majority of the prime ministers of the last 50 year period would agree.]

(Ash 27 April 2007; translation by I Kathimerini; back-translation and emphasis by the authors)

These are traces of predictable behavior, assuming a social science perspective into language and translation. They are employed in the target version to improve discourse texture, no matter the (favorable or critical) perspective to Mr. Blair's premiership assumed in the article. They may be contributing to author intention and to strengthening the ideological stance of the text, but the shifts appear almost invariably on the Greek language side, no matter the direction of translation. The next section highlights shifts which are less predictable, though still within the potential of the language.

\subsection{Creative and voluntary behavior}

Creative and voluntary behavior encompasses shifts which may be culturally motivated but have a fairer share in constructing or sustaining world representations, in agreement with intended ideological perspectives. Shifts in metaphor use and collocational meaning reveal alternative conceptualizations of the world and partly manifest voluntary and creative behavior, because they could have been avoided without playing down text naturalness; they would have rather affected the communicative potential of the text.

As Kövecses claims "[u]nconventionality is not necessarily tied to poetic or literary language" (Kövecses 2006: 127). News reporting seems to be making ample use of metaphors, conventional and unconventional ones, in support of the point of view of text producers. For instance, Fairclough analyzes implications following from dealing with drug trafficking as fighting a war, in a article published in the Sun in 1985:

Notice also the metaphor of dealing with drug traffickers as fighting a war [...]. The metaphor is also significant in terms of the newspaper's implicit claim to a relationship of solidarity and common identity with the audience. It draws upon war as an evocative theme of popular memory and popular culture. [...] It is an ideologically potent metaphor constructing drugs in a way which helps to marginalize other constructions from the perspective of oppositional groups... (Fairclough 1995: 71-72)

The target version of the data activates the war metaphor through rendering the

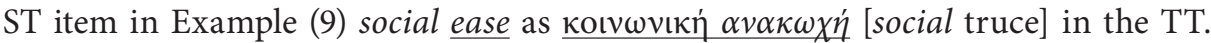
Activation of the war metaphor, in text-pair b (the one conveying the negative view), is not unmotivated. It is assumed to be legitimizing the difficulty of Mr. Blair's compromising conflict, which would have a diminishing effect on the negative view conveyed by the text.

(9) After 10 years of economic growth, social ease, [...] Blair has managed to get himself roundly, fundamentally, panoramically hated at home.

(Gill 24 June 2007)

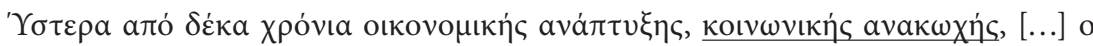

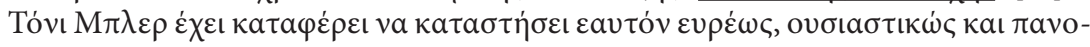

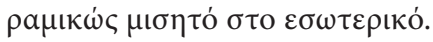


[After 10 years of economic growth, social truce, [...] Tony Blair has managed to make himself broadly, fundamentally and panoramically hated at home.]

(Gill 1 July 2007; translation by I Kathimerini; back-translation and emphasis by the authors)

A metaphor which seems to enjoy currency in the target text and is invariably used in both target articles draws on the politics is a stageplay conceptualization, as shown in the following TTs (Examples [10] and [11]). The game metaphor (Hollander 2010) manifested through ST item key player, does not seem to be as common as in the Greek version, which seems to prefer the stage metaphor instead, as manifested by TT items $\underline{\delta\llcorner\alpha \rho \alpha \mu \alpha \tau i \zeta \varepsilon ı ~[a c t s ~ o u t] ~ o r ~} \underline{\delta \omega \omega} \mu \varepsilon v \alpha$ [(stage) activity]:

(10) [I]t remains a key player on most major issues [...] Blairism is, he elaborates, about a progressive view of the world.

(Ash 26 April 2007)

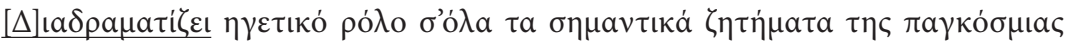

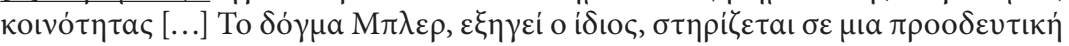

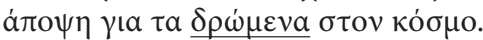

[it acts out a leading role in all significant issues of the global community [...] Blairism, he explains, is based on a progressive view of global (stage) activity).]

(Ash 27 April 2007; translation by I Kathimerini; back-translation and emphasis by the authors)

Similarly, Example (11) below activates the politics is a stageplay analogy: cajole is rendered as $\underline{\varepsilon} \delta \rho \alpha \sigma \alpha v \sigma \tau o \pi \alpha \rho \alpha \sigma \kappa \eta \dot{v} \iota 0$ [acted at backstage].

(11) Tony Blair's administration was branded and packaged by relentless public relations. Everything was first and last about perception and presentation. His people cajoled, begged, charmed, bribed, flattered and postured to make the electorate love them. And in return, the electorate hated them even more for being so embarrassingly transparent and shamelessly insincere.

(Gill 24 June 2007)

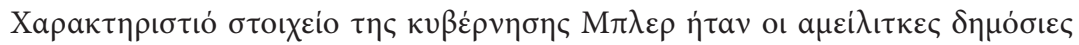

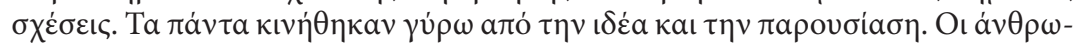

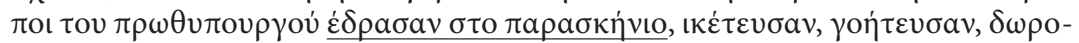

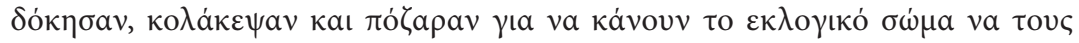

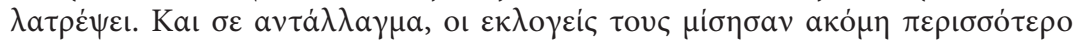

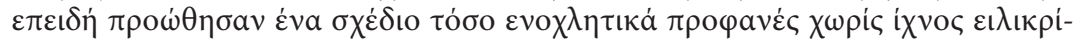
velac.

[A typical feature of Tony Blair's governmemt was relentless public relations. Everything was about concept and presentation. The people of the prime minister acted at backstage, begged, appealed, bribed, flattered and postured to make the electorate love them. And in return, the electorate hated them even more for having promoted a plan so annoyingly evident without any trace of sincerity.]

(Gill 1 July 2007; translation by I Kathimerini; back-translation and emphasis by the authors)

Although creative and voluntary (linguistic) behavior is realized through the options available in a language, its subjective nature allows some interpretation which may implicitly generate meaning: the politics is a stageplay conceptual metaphor 
seems to be placing the audience in the position of a spectator who is rather unlikely to contribute to action, and may assume a society displaying rather low civic engagement. The next example (from Ash [2007], the one which conveys the favorable attitude towards Mr. Blair) lends support to the low civic engagement view in that it favors a conceptualization of an active and powerful leader in the opening paragraph, activating the horse-riding metaphor (the state/Britain is a horse), with the leader being the horse-rider.

(12) Tony Blair bounds into the garden of 10 Downing Street, looking as if he's ready for another 10 years there.

(Ash 26 April 2007)

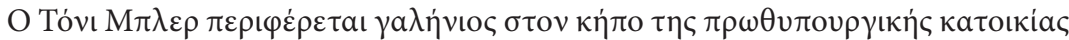

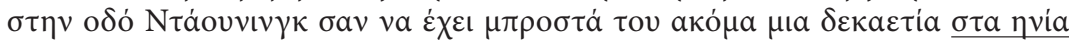

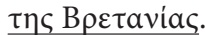

[Tony Blair strolls peacefully in the garden of prime-ministerial quarters as if he's ready for another decade at the bridle of Britain.]

(Ash 27 April 2007; translation by I Kathimerini; back-translation and emphasis by the authors)

A less conventional (and hence more creative) conceptualization is realized through intertextual reference (Hatim and Mason 1991) manifested through the religious terminology employed in Example (13) in rendering removing Taliban, toppling Saddam as a and Saddam]. The shift attributes a sacred gloss to Taliban and Saddam and privileges Blair's contribution to conflict resolution, in the text-pair conveying the positive view.

(13) In his time, Britain has played a significant part in hard power actions, whether removing the Taliban, toppling Saddam, in Kosovo or in Sierra Leone; it has done the same in soft power areas, such as Africa and climate change.

(Ash 26 April 2007)

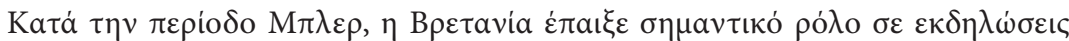

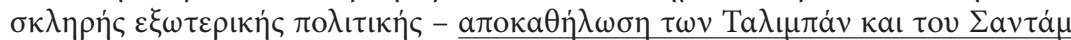

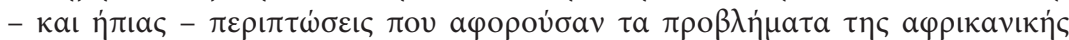

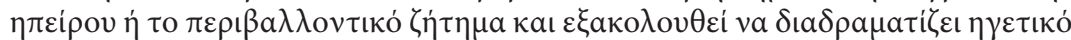

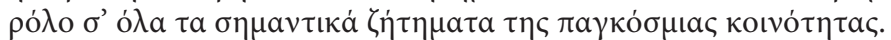

[In the Blair period, Britain played a key role in hard foreign affair actions - the unnailing of Taliban and Saddam - and soft ones - in cases concerning problems of the African continent or the environmental question, and it still acts out a leading role in all significant issues of the global community.]

(Ash 27 April 2007; translation by I Kathimerini; back-translation and emphasis by the authors)

In Example (14), a pro-Middle East target orientation may be traced in rendering

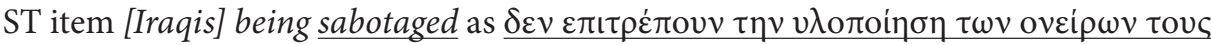
[not allowing implementation of their dreams]. The sabotage option is available in Greek (as a loan item, $\sigma \alpha \mu \pi 0 \tau \alpha \dot{\rho} \omega$ ) but the preferred implementation of dreams option allows a humanitarian perspective to areas suffering war and oppression. 
(14) The overwhelming majority of ordinary Iraqis want peace and democracy, but they are being sabotaged by "external players" - he mentions Iran and al-Qaida - plus "a minority of internal extremists."

(Ash 26 April 2007)

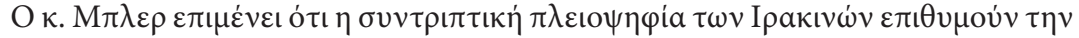

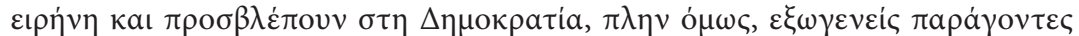

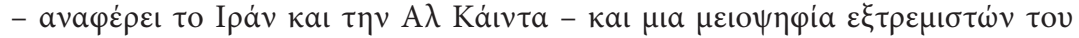

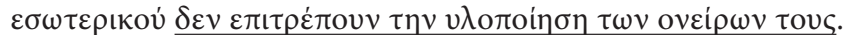

[Mr. Blair insists that the overwhelming majority of Iraqis want peace and democracy, however "external players" - he mentions Iran and al-Qaida - plus "a minority of internal extremists" do not allow implementation of their dreams.]

(Ash 27 April 2007; translation by I Kathimerini; back-translation and emphasis by the authors)

The creative and voluntary behavior section shows a range of expressions, manifesting partly conventional, partly creative use of the language, which contributes conceptualizations compatible with author intention and ideological orientation of the article. This is also partly changeable behavior, shifts which manifest a power struggle site. The next section elaborates on ST content selection which lends support to TT intended ideological perspectives.

\subsection{Changeable behavior: culture as a site for power struggle}

Exploration of the journalist-translators' behavior, beyond the predictable and voluntary/creative levels of decision-making was motivated by an interest in exploring conventions which govern selection of content, as source texts are usually considerably longer than target versions. An obvious criterion is the Gricean maxim of relevance (Hatim and Mason 1991, Baker 1992/2011). Relevance is renegotiated in the target situation and functions as a gate-keeping mechanism. Some themes are invariably favored in both target texts, no matter the ideological stance, others are omitted as irrelevant. For instance, both Ash (2007) and Gill (2007) prioritize UK-US power balance and shifts in identity, evidently because their role as key players and the distribution of power globally is assumed to be highly relevant. In Example (15), TT prioritizes US power over UK, by selecting the (underlined) item out of a drastically condensed version of ST extract.

(15) A great deal of that [Euroscepticism] is due to the Eurosceptic media. Europe is an area above all "where I'm urged by even quite sensible parts of the media to do things that I know are completely daft, and that anyone sitting in my chair would think are completely daft. [...] As for Britain's other pivotal alliance, what, I ask, has Britain actually got out of its "special relationship" with Washington over the last decade? [...] "Time we had an independent foreign policy," is the easiest applause-line in the world, but start distancing yourself from the US and see how your influence will be diminished.

(Ash 26 April 2007)

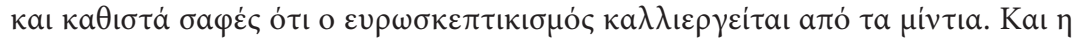

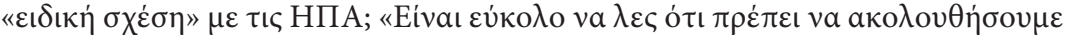

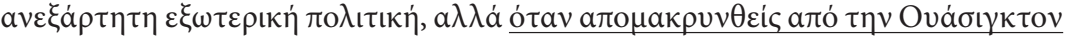

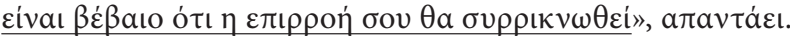


[and he makes it clear that euroscepticism is cultivated by the media. And the "special relationship" with the US? "It is easy to say that we have to have an independent foreign policy, but when you distance yourself from Washington your influence surely shrinks" he replies.]

(Ash 27 April 2007; translation by I Kathimerini; back-translation and emphasis by the authors)

TT also makes sure it privileges a US-UK comparison in presidency reception, with the US assumed to be exhibiting the most decent behavior (Example [18] provides an instance of this). In the same vein, aspects of the British history and identity may not be considered as relevant and are thus not selected for inclusion in the TT, as the section in Example (16):

(16) The Duke of Wellington, vanquisher of Napoleon, most respected and regarded man in Europe, a 19th-century Eisenhower, foolishly allowed himself to be made prime minister and became instantly reviled. He was once [...]. Hatred of authority figures and rule-makers might all be an amusing part of the national character, the collective DNA - a Falstaffian, trenchant, robust skepticism to be admired, if it hadn't grown so destructive and so intimidating.

(Gill 24 June 2007)

The paper claims that the relevance criterion encompasses awareness of political routines and practices, which are silenced or highlighted in compliance with intended representations of the world. For instance, an aspect of experience, which is silenced in TT, is the leader's dependence on government apparatus and advisors in decisionmaking, as manifested in that a farewell trip of the prime minister was cancelled because advisors had second thoughts about it. In Example (17), ST is part of the opening paragraph which is missing in TT. The omission is ideologically significant in that it rounds off the negative gloss of the source article by silencing information which contradicts the leading role of the prime minister.

(17) The trip hung in the air for a bit, then the advisers had second thoughts and tweaked the itinerary. It would all stay the same - hospitals, schools, nature, hugs and so on - but the venue would move. He'd do Africa instead. Africa, it was thought, would be more sympathetic, grateful. The Libyan dictator Muammar el-Qaddafi liked him better than the voters of Macclesfield and Solihull. And they felt, all things considered, Africa would be safer.

(Gill 24 June 2007)

Why should the leading role of a prime minister be significant? There seem to be political-communication-relevant reasons for privileging this piece of information. In describing prime ministerial government, Heywood verifies a shift in British politics with Blair's premiership: "the cabinet has been turned into a US-style advisory body that no-longer exercises policy-making responsibility. [...] In any respect, Tony Blair's premiership after 1997 built on these foundations" (Heywood 2007: 369). A critical perspective into information selection would reveal that a principle governing in-/ex-clusion of information in the Greek TT relates to a set of features of presidentialism claimed in political theory to be exhibited by parliamentary executives.

These features are: 
- spatial leadership: the tendency of prime ministers to distance themselves from their parties and governments by presenting themselves as 'outsiders' or developing their own ideological stance;

- populist outreach: the attempt by prime ministers to engage directly with the public by claiming to articulate their deepest hopes and fears;

- personalized election campaigns: the news media's obsession with personality and the trend to portray leaders as the 'brand image' of their parties or governments;

- personal mandates: the trend of prime ministers to claim electoral authority and to view themselves as the ideological consciences of their parties or governments;

- special advisors: the trend for prime ministers to rely on hand-picked political advisors rather than cabinets, ministers or senior civil servants.

(Heywood 2007: 369)

The Example (17) (Gill 24 June 2007) extract is omitted in the TT (Gill 1 July 2007 , translated by the newspaper I Kathimerini) because it contradicts the spatial leadership feature. The spatial leadership criterion is also a background consideration which justifies selection of TT in Example (12): it seems to have been selected because it presents the prime minister on his own, distanced from his party or government, in agreement with the spatial leadership feature. Although special advising is a norm in premierships, this piece of information is eliminated in the TT, in favor of a rather naïve image of a premier whose reasoning capacity and common sense allows him to act somewhat independently.

An open research problem is to what extent a political community or a particular social class which the paper addresses favors (degrees of) charismatic authority or legal-rational authority (Heywood 2007: 220). The issue is beyond the scope of the present research, but the assumption is that press translation is likely to register such shifts in political rule preference and political legitimacy as a sociological phenomenon.

In Example (18), the journalist-translators' behavior is governed by awareness of the significance of the second feature of presidentialism, populist outreach. For instance, the article by Gill (24 June 2007), which carries the negative gloss, transposes the locus of conflict by silencing the Blair/media opposition and privileging the Blair/public one (as is also manifested in the TT headline: Blair, a scapegoat for the British, which translates ST The New York Times headline, Tony Blair: Three-time loser). Attention is thus drawn to Mr. Blair's flouting the populist outreach feature. Example (18) refers to a difference in the way the leader is received in the US/UK, which touches upon the "populist outreach" feature of presidentialism. The relationship of heads of state with the public has been selected for inclusion, as indicated in Example (18) because the populist outreach feature is at stake: lack of the populist outreach potential in the UK context (when premier leaves office) contributes to the unfavorable gloss of the article.

(18) The difference between British politics and American is that you maintain a collective respect for the office, if not the holder. So the presidency is a venerable thing, even if the president is a cretin.

(Gill 24 June 2007)

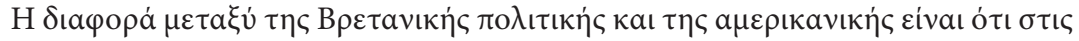

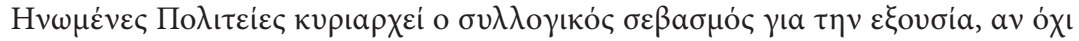

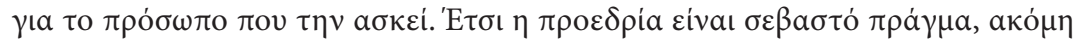

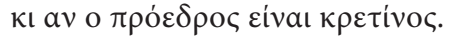


[The difference between British politics and American is that in the US a collective respect for the office prevails, if not the holder. So the presidency is a venerable thing, even if the president is a cretin.]

(Gill 1 July 2007; translation by I Kathimerini; back-translation and emphasis by the authors)

No wonder Ash (26 April 2007), which carries the positive gloss, silences information which would contradict the last two features of presidentialism on the Heywood list, namely "personal mandates" and "special advisors": as shown in Example (15) (the omitted fragment in the ST appears in italics), the target version silences Mr. Blair's complaint that the media is a participant whose power overrides "personal mandates" or any "special advice." By contrast, information on special advisors is selected in Example (11) (Gill 1 July 2007) for highlighting their inefficiency, in agreement with the negative gloss conveyed by the article.

Political routines and practices, such as features of presidentialism, seem to affect information transfer through translation. All shifts in Ash (27 April 2007), creative/ voluntary or changeable, had a potential to strengthen the ideological stance of the TT; they had a pro-Blair orientation (e.g., Examples [12], [13], [14] and [15]). Conversely, the shifts in Gill (1 July 2007) did allow the negative gloss of the ST, however mitigated through some shifts (Examples [9] and [17]) which rather rounded off The New York Times negative stance towards Mr. Blair.

The data show that there is a bulk of background knowledge relevant to political communication routines, legitimacy, etc. - in addition to linguistic aspects of meaning-making which contribute their own implicit unquestioned meaning emerging from text structure - thus regulating information inflow (in TTs) as a gatekeeping mechanism.

\section{Political theory and translation theory}

The article intends to highlight the significance of political routine awareness in press translation decision-making, which translation theory usually groups under "generic/ (journalistic) conventions." News translation is immensely privileged by, but should not be confined to, the study of linguistic routines that regulate journalist-translators' decision-making. Attention should be directed to the political routines which contribute to the gate-keeping mechanism, no matter the function we assume of the media - the propagandistic one as claimed by Chomsky and Herman (1988/1994), or the alleged flexibility and adaptability tendency of the media to a "dynamic political system, governed not by a single ruling class but by rotating elites drawn from different parties and factions within parties" (McNair 1995/2011: 60).

If nowadays politics has become "not only a persuasive but a performance act, in which considerations of style, presentation and marketing are of equal if not greater importance than content and substance" (McNair 1995/2011: 60), the shift is likely to be reflected in texts through adjustments which conform to the dictates of presentation and marketing. Political representation in modern democracies and the construction of political persona assumes a combination of politics and popular aesthetics (Street 2004). As long as popular aesthetics develops or varies across cultures, textual representations of it are expected to vary as well. In this vein, section 2.3 hinted upon 
the significance of shifts in sociopolitical phenomena (political legitimacy and rule) as potential parameters affecting decision-making in press translation.

Another political routine which has been left rather unexplored and is likely to trigger shifts in cross-cultural transfer in the press, is the type of media impact assumed of the source/target newspapers. For instance, to the best of our knowledge, there has been no research investigating shifts in the models of media impact manifested through translation, i.e., shifts in the pluralist, dominant-ideology, elite-values, and market model conventions, which govern news construction. In political theory, the impact of the media has been accounted for in terms of a set of models which range from pluralist (highlighting "diversity and multiplicity" [Heywood 2007: 233]) to dominant-ideology (portraying media as promoting "compliance or political passivity amongst the masses" [Heywood 2007: 233]), elite-values (shifting attention from media ownership to the "mechanism through which the media output is controlled [Heywood 2007: 234]) and market models (assuming media to be reflecting rather than shaping the views of the public).

Message transfer across cultures and media is likely to exhibit shifts across media impact types. Mass media are powerful political actors and secondary agents of political socialization (with family and school being primary agents [Heywood 2007]), therefore studying translation in the media cannot neglect awareness of the interdisciplinary potential of the enterprise.

There seems to be a considerable overlap between political theory and translation theory, as both are disciplines dealing with decision-making (of the politician, or the translator) which addresses and has impact on the public. They both deal with phenomena of conflict and cooperation between competing needs of social groups and languages. The various views about what politics is, as described in political theory, seem to have a parallel with views about what translation entails. For instance Heywood explains that politics has been viewed, through the ages, as

- the art of government, namely "the exercise of control within society through the making and enforcement of collective decisions" (Heywood 2007: 5);

- public affairs, namely "the collective organizations of community life" (Heywood 2007: 8);

- compromise and consensus, namely "means of resolving conflict: that is compromise, conciliation and negotiation, rather than through force and naked power" (Heywood 2007: 9);

- power distribution and distribution of resources, in the broad sense, meaning that "[p]olitics is in essence power: the ability to achieve a desired outcome, through whatever means." (Heywood 2007: 11)

Likewise, in translation theory, translation has been viewed as an art (especially through a literary criticism perspective), as public affairs (in the sense that source and target texts can reflect the social identities of their respective environments), as compromise and consensus (in the sense that there is a lot to be compromised and negotiated: identities, ideologies, interests), and as power distribution or distribution of resources (in the sense of achieving or maintaining world dominance), as claimed through Valdeón’s (2011) Falklands-Malvinas binomial case. Translation studies (and media translation research and training - in particular) is expected to immensely benefit from a closer look at issues and themes in political theory. 


\section{ACKNOWLEDGMENTS}

We are indebted to our two anonymous referees.

\section{NOTES}

1. Ash, Timothy Garton (26 April 2007): Like it or loathe it, after 10 years Blair knows exactly what he stands for. The Guardian. Visited on 19 June 2011, <http://www.guardian.co.uk/commentisfree/2007/apr/26/comment.labour>.

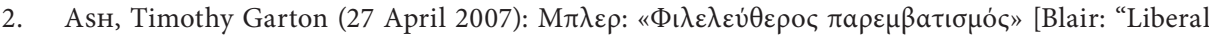

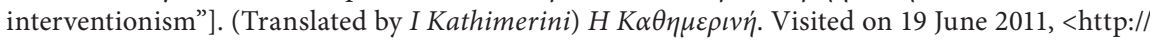
news.kathimerini.gr/4Dcgi/4Dcgi/_w_articles_civ_12_27/04/2007_224964>.

3. Gill, Adrian Anthony (24 June 2007): Tony Blair, Three-Time Loser. The New York Times. Visited 19 June 2011, <http://www.nytimes.com/2007/06/24/opinion/24gill.html?pagewanted=all\&_r=0>.

4. GiLl, Adrian Anthony (1 July 2007): A scapegoat for the British]. (Translated by I Kathimerini) $H$ K $\alpha \theta \eta \mu \varepsilon \rho v \eta$. Visited on 19 June 2011, <http://news.kathimerini.gr/4Dcgi/4Dcgi/_w_articles_columns_2_01/07/2007_232802>.

\section{REFERENCES}

BAKER, Mona (1992/2011): In Other Words. London: Routledge.

BAKer, Mona (2006): Translation and Conflict - A Narrative Account. London: Routledge.

Bielsa, Esperança and BAssnett, Susan (2009): Translation in Global News. New York: Routledge.

Chomsky, Noam and Herman, Edward S. (1988/1994): Manufacturing Consent: The Political Economy of the Mass Media. London: Vintage.

Fairclough, Norman (1995): Media Discourse. London/New York: Arnold.

Hatim, Basil and Mason, Ian (1991): Discourse and the Translator. London: Longman.

Heywood, Andrew (1997/2002/2007): Politics. New York: Palgrave Macmillan.

Hofstede, Geert and Hofstede, Gert Jan (2005): Cultures and Organizations - Software of the Mind. New York: McGraw-Hill.

Kontos, Petros and Sidiropoulou, Maria (2012): Socio-political Narratives in Translated English-Greek News Headlines. Intercultural Pragmatics. 9 (2):195-224.

Kövecses, Zoltán (2006): Language, Mind and Culture. Oxford: Oxford University Press.

Martin, Judith N. and NAKAYAmA, Thomas (2003): Intercultural Communication in Contexts. Boston: McGrow Hill.

McNaIr, Brian (1995/2011): An Introduction to Political Communication. London/New York: Routledge.

Munday, Jeremy (2001/2008): Introducing Translation Studies. London/New York: Routledge. VAN LeEUwEN, Theo (2011): Translation, Adaptation, Globalization - The Vietnam News. Journalism. $7(2): 217-237$.

Sidiropoulou, Maria (2004): Linguistic Identities through Translation. Amsterdam/New York: Rodopi.

Sidiropoulou, Maria (2008): The translator as social scientist: the T.E.G.MA. compilation project. In: Teaching and researching the practice: Professional identity, translation/interpretation education, new technologies (2nd Athens International Conference on Translation and Interpretation, HAU, Athens, 10-11 October 2008). Visited on 19 June 2011, <http:// translation.hau.gr/telamon/files/Sidiropoulou_Paper.pdf $>$.

Sifianou, Maria (1992): Politeness Phenomena in England and Greece. Oxford: Clarendon.

Street, John (2004): Celebrity politicians: Popular culture and political representation. The British Journal of Politics and International Relations. 6(4):435-452.

VALDEÓn, Roberto (2005): The “Translated” Spanish Service of the BBC. Across Languages and Cultures. 6(2):195-220.

VALdEón, Roberto (2011): Embedding Anglocentric perceptions of the world: The FalklandsMalvinas binomial in the news. Meta. 56(1):63-80.

Verschueren, Jef (1999): Understanding Pragmatics. London/New York: Arnold. 